positive predictive value was $10 \%{ }^{10}$-for every cancer found nine women had a positive result on screening, of whom seven had a biopsy taken. Warren quotes European studies with positive predictive values of $30-60 \%$ and suggests that $25 \%$ is an acceptable standard. In the Forrest report a ratio of benign to malignant of two to one on biopsy is cited as appropriate, suggesting a positive predictive value of $33 \%$ - but there is no further discussion.

Kopans and Swann have focused on this discrepancy between the North American and European studies $^{15}$ and suggested that in Europe there is a greater acceptance of a "wait and see" follow up with repeated mammography, whereas in the United States there is more pressure from patients and doctors for immediate biopsy even when malignancy does not look likely. It is not known what the optimal positive predictive value should be, but the $33 \%$ of the Forrest report seems too high, and the $5-10 \%$ quoted by Skrabanek is too low. A value that is too high means that some cancers will be missed whereas a low value means that many women will have unnecessary biopsy. Wright suggested that mammography screening should be reserved for women with high risk factors,${ }^{6}$ but three quarters of all cancers occur in women with no risk factors.

Present evidence suggests that mammography screening saves lives and that the risks from radiation are negligible or non-existent. ${ }^{16}$ British screening policy has targeted only those most at risk, and, as Warren points out, the programme offers less frequent screenings to fewer women than the programmes in other European countries. The economy of a single view examination will clearly mean more recalls than with a two view examination.

Establishment of even this limited national screening service is going to be costly. If many more positive results are produced from screening than Forrest anticipated and if the screening is extended to younger women and incorporates more frequent examination the costs are going to be greater. It remains to be seen how busy radiologists, surgeons, pathologists, and their support staff in general hospitals cope with the extra workload that the programme is certain to produce.

JOHN REIDY

Consultant Radiologist

OSMOND HOSKINS

Guy's Hospital, Emeritus Consultant Radiologist

London SE1 9RT

1 Department of Health and Social Security. Breast cancer screening. London: HMSO, 1986. (Forrest report.)

2 Tabar L, Fagerberg CJ, Gad A, et al. Reduction in mortality from breast cancer after mass screening with mammography. Lancet 1985; ; $829-32$.

Shapiro S, Venet P, Strax P, Roeser R. Ten to fourteen year effect of screening on breast cancer mortality. FNCI 1982;69:349-55.

mortality. FNCI 1982;69:349-55.
Moskowitz M. Breast cancer screening. Surgery 1987;102:106-9.

4 Moskowitz M. Breast cancer screening. Surgery 1987;102:106-9.
5 Feig S. Decreased breast cancer mortality through mammography screening: results of clinical Feig S. Decreased breast cancer mo
trials. Radiology 1988;167:659-65.

6 Wright CJ. Breast cancer screening: a different look at the evidence. Surgery 1986;100:594-8.

Shapiro S. Breast cancer screening. Surgery 1987;102:109-10.

8 Wright CJ. Breast cancer screening. Surgery 1987;102:113-4.

9 Ellman R. Breast cancer screening. F R Soc Med 1987;80:665-6.

10 Baker LH. Breast cancer detection demonstration project: five year summary report. CA 1982 42:1-35.

11 Verbeek AL, Holland R, Sturmans F, Hendricks JH, Mravunac M, Day NE. Reduction of breas screening mortality through mass screening with modern mammography. Lancet 1984;i:1222-4. 2 Collette HJ, Day NE, Rombach JJ, De Waard F. Evaluation of screening for breast cancer in a nonrandomized study (the DOM project) by means of a case-control study. Lancet 1984;i:1224-6.

13 Moskowitz M. Predictive value, sensitivity and specificity in breast cancer screening. Radiology 1988;167:576-8

14 Baines CJ, Miller AB, Wall C, et al. Sensitivity and specificity of first screen mammography in the Canadian National Breast Screening Study: a preliminary report from 5 centres. Radiology 1986;10:295-8

15 Kopans DB, Swann CA. Observation on mammographic screening and false-positive mammo-

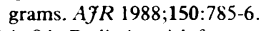

16 Feig SA. Radiation risk from mammography: is it clinically significant? AfR 1984;143:469-75.

\title{
Temporal artery biopsy
}

\section{More important the less classic the presentation}

To miss the diagnosis of giant cell arteritis may be disastrous. Yet its treatment is usually rewarding. Opinions differ on the usefulness of biopsy of the temporal artery because a negative result cannot exclude arteritis. Some suggest that biopsy should be reserved for patients failing to respond promptly to corticosteroids. ${ }^{1}$ Others assiduously seek histological confirmation of their diagnosis by removing several centimetres of superficial temporal artery and, if this does not produce a result, performing a biopsy of the contralateral artery. ${ }^{23}$

There is no disagreement that an elderly patient with a recent onset of headache, jaw claudication, and a tender or thickened temporal artery requires prompt treatment with corticosteroids to prevent blindness. ${ }^{+}$The combined presence of these features predicts a positive finding on biopsy in all but about $5 \%$ of cases. ${ }^{5}$ A negative result will not alter management in straightforward cases, and biopsy is not essential.

More commonly patients present with recent headache and muscle symptoms. In such patients a raised erythrocyte sedimentation rate is a useful pointer but cannot be totally relied on to screen for patients requiring biopsy. Visual loss may develop in patients with symptoms of giant cell arteritis and a normal or minimally raised erythrocyte sedimentation rate. ${ }^{6}$ The message is that superficial headache of recent onset occurring daily for two weeks or more in a patient over 55 should always be taken seriously - a biopsy of the temporal artery should be considered. Routine biopsy is probably not

required for patients presenting with just polymyalgia rheumatica unless symptoms suggestive of arteritis emerge on direct questioning or follow up.

Biopsy of the temporal artery may be particularly valuable in elderly patients presenting with fever of undetermined origin ${ }^{78}$ obscure anaemia, ${ }^{9}$ or anorexia and weight $\operatorname{loss}^{10}$ but without the classic symptoms of giant cell arteritis. Such patients may be subjected to many investigations for occult malignancy or infection. ${ }^{.1}$ The need for these investigations is obviated if giant cell arteritis is considered and the finding on biopsy is positive.

If biopsy is to be performed in patients already receiving corticosteroids it should be done within a week of their starting treatment. The diagnostic yield declines if the biopsy is delayed beyond one week, ${ }^{12}$ and the changes of healed arteritis may be difficult to distinguish from arteriosclerosis. ${ }^{13}$ Healed arteritis has characteristic histological features, ${ }^{14}$ but these are found only occasionally. ${ }^{12}$ Preoperative flow studies using Doppler ultrasonography may help to pinpoint affected segments of artery ${ }^{15}$ but are unlikely to be an important advance because temporal arteriography has proved disappointing. ${ }^{16}$

To increase the diagnostic yield of biopsy both arteries should be palpated for areas of tenderness or thickening and the course of the artery marked before local anaesthesia is given. The aim is to remove at least $2 \mathrm{~cm}$ of artery without 
injuring the chosen segment. ${ }^{17}$ Sadly, the procedure is often left to the unsupervised beginner. All biopsy specimens should be serially sectioned because skip lesions as short as $0.35 \mathrm{~mm}$ may occur. ${ }^{18}$

Biopsy of the temporal artery remains a useful confirmatory investigation in patients with giant cell arteritis. Long term treatment with corticosteroids and follow up may be started confidently if histological proof of the condition is obtained. The decision to treat the minority of patients in whom the findings on biopsy are negative must be made on clinical grounds. If the diagnosis is seriously suspected prompt treatment should be started without waiting for confirmation from biopsy.

Senior Medical Registrar,

MILES C ALLISON

Western Infirmary and Gartnavel General Hospital,

Glasgow

1 Allsop CJ, Gallagher PJ. Temporal artery biopsy in giant-cell arteritis. A reappraisal. Am f Surg Pathol 1981;5:317-23.
2 Hall S, Persellin S, Lie JT, O'Brien PC, Kurland LT, Hunder GG. The therapeutic impact of temporal artery biopsy. Lancet 1983;ii: 1217-20.

Hall S, Hunder GG. Is temporal artery biopsy prudent? Mayo Clin Proc 1984;59:791-6.

4 Bengtsson BA, Malmvall BE. Giant cell arteritis. Acta Med Scand [Suppl] 1982;658:1-102

5 Vilaseca J, Gonzalez A, Cid MC, Lopes-Vivancos J, Ortega A. Clinical usefulness of temporal artery biopsy. Ann Rheum Dis 1987;46:282-5.

6 Ellis ME, Ralston S. The ESR in the diagnosis and management of the polymyalgia/giant cell arteritis syndrome. Ann Rheum Dis 1983;42:168-70.

7 Ghose MK, Shensa S, Lerner PI. Arteritis of the aged (giant cell arteritis) and fever of unexplained origin. Am F Med 1976;60:429-36.

8 Healey LA, Wilske KR. Presentation of occult giant cell arteritis. Arthritis Rheum 1980;23:641-3. Healey LA, Wilske KR. Anemia as a presenting manifestation of giant cell arteritis. Arthritis Rheum 1971;14:27-31.

10 Strachan RW, How J, Bewsher PD. Masked giant cell-arteritis. Lancet 1980;i:194-6.

11 Allison MC, Gough KR. Steroid sensitive systemic disease with anaemia in the elderly: a manifestation of giant cell arteritis? Postgrad Med f 1985;61:501-3.

12 Allison MC, Gallagher PJ. Temporal artery biopsy and corticosteroid treatment. Ann Rheum Dis 1984;43:416-7.

13 Ainsworth RW, Gresham CA, Balmforth GV. Pathological changes in temporal arteries removed from unselected cadavers. $\mathcal{F}$ Clin Pathol 1961;14:115-9.

14 Lie JT, Brown AL, Carter ET. Spectrum of aging changes in temporal arteries. Its significance in

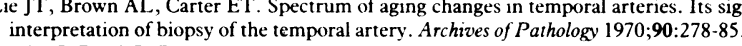

15 Barrier J, Potel G, Renaut-Hovasse H, et al. The use of Doppler flow studies in the diagnosis of giant cell arteritis. FAMA 1982;248:2158-9.

16 Sewell JR, Allison DJ, Tarin D, et al. Combined temporal arteriography and selective biopsy in suspected giant cell arteritis. Ann Rheum Dis 1980;39:124-8.

17 Russell RCG. Biopsy of specific tissues. In: Dudley H, Carter DC, Russell RCG, eds. Atlas of general surgery. London: Butterworth, 1986:27-32.

18 Klein RG, Campbell RJ, Hunder GG, Carney JA. Skip lesions in temporal arteritis. Mayo Clin Proc 1976;51:504-10.

\title{
Trouble with health maintenance organisations
}

\author{
No panacea for either Britain or the United States
}

Health maintenance organisations are an American invention for supplying health care in a way that contains costs. Some of the principles of the organisations are now being enthusiastically advocated in Britain, which should increase British interest in some of the recent problems faced by the organisations.

The basic idea of the health maintenance organisations is that consumers enrol in a health plan, normally every year for a yearly premium. This then entitles the consumers to care stipulated under the conditions of the particular organisation. Health maintenance organisations may be divided into three rough categories. Comprehensive organisations employ salaried doctors, own their own hospital facilities, and cover most types of health care, including primary care. Mixed health maintenance organisations have some of the same features as comprehensive organisations and yet contract some care out to independent hospitals that charge fees for their services; they may provide more limited cover than comprehensive organisations. Foundation organisations pay doctors by fees for services but often build in an incentive for them not to provide too much care - they may receive a bonus or "profits" based on either the organisation's profits or their ability to work within their budget and save resources.

In the 1970s health maintenance organisations were generally promoted by liberals, and federal legislation stipulated that the most sick and those at greatest risk of illness could not be charged more than the average consumer and that there must be periods of time when all comers could register, with nobody being rejected as a bad risk. These stipulations stopped health maintenance organisations being financially viable. Massive federal subsidies or public provision of health maintenance organisations would have been necessary to allow them to adopt these progressive policies. As a result the restrictive federal legislation was loosened.

Health maintenance organisations failed to grow in the 1970 s to the extent expected, but by 1985 it was estimated that coverage of the population by health maintenance organisations was expanding at $15 \%$ a year. But instead of being an embryonic challenge to the existing American health care system, health maintenance organisations are now largely a component of the market system. Health maintenance organisations for profit have grown particularly fast, and the organisations generally have prospered in the more affluent areas, especially on the east coast and in California. By and large health maintenance organisations prosper by skimming the market and not accepting particularly poor risks. They have recently been criticised heavily for being bad at providing long term care and care of priority groups such as the elderly and patients needing emergency care. Thus many organisations do not provide emergency care for nonresidents of the states in which they are located.

By the end of 1987 about 28 million Americans were members of health maintenance organisations and growth rates were reaching $18 \%$ a year. But now even the fastest growing profit making organisations are often making losses and cutting services. The reaction has been to raise premiums, sell assets, and get rid of staff. Both profit making and non-profit making organisations are in trouble, including many sponsored by Blue Cross or Blue Shield.

Because of the profligacy and waste of the American system of a fee for a service there was great scope for health maintenance organisations - and preferred provider organisationsto tackle inefficiencies with the techniques of corporate management. But health maintenance organisations are clearly not a panacea for the whole healthcare system. There are still at least 36 million Americans who are completely uninsured, and alternative solutions to national problems, such as the old hope of national health insurance, are being revitalised. The yearly growth of hospital costs has again doubled from a decrease in 1984-5, and the capacity of health maintenance organisations to cut costs-let alone promote equity - is seriously in doubt.

So what does this mean for Britain? The type of American health maintenance organisation that has led to the greatest control of costs is that of the "primary physician gatekeeper"; this relies on primary physicians (general practitioners) to conserve resources by rationing access to specialised services. It has been argued that health maintenance organisations 